\title{
Membangun Hubungan Komisi Yudisial Dengan Mahkamah Agung Yang Ideal
}

\author{
Juanda $^{1}$, Ogiandhafiz Juanda ${ }^{2}$ \\ ${ }^{1}$ Guru Besar Fakultas Hukum, Universitas Bhayangkara Jakarta Raya \\ ${ }^{2}$ Dosen Fakultas Hukum, UNAS Jakarta \\ Email: prof.juanda1963@gmail.com
}

Received : 20 Nop 2021 | Revised : 1 Dec 2021 | Accepted : 3 Dec 2021 | Published : 9 Dec 2021

\begin{abstract}
The phenomenon of the relationship between the Judicial Commission (KY) and the Supreme Court (MA) has had its ups and downs, and there are still many misinterpretations, as well as no common paradigm. As a result, if left unchecked, it could have a wide-ranging impact on law enforcement and justice in Indonesia's justice system. There are many aspects that need to be developed namely by establishing common paradigm and evaluating each party's duties and authorities in order to achieve a harmonious relationship and strong synergy. Based on the problematic relationship between the two state institutions, the author is interested in studying and discussing "Building an Ideal Relationship between the Judicial Commission and the Supreme Court". In order to examine and discuss the issue more fundamentally, the writer formulates the problem as follows: "How is the effort to build an ideal relationship between the judicial commission and the Supreme Court?" The method used is in accordance with the type of research, which is normative juridical and involves the use of both primary and secondary legal materials. While the analysis that was used is a qualitative juridical analysis. The conclusion is that the paradigm of the relationship that must be built between the judicial commission and the Supreme Court is the paradigm of equality, systematic, professionalism and proportionality. Efforts that can be made are to strengthen communication, coordination, and review and evaluate various obstacles and weaknesses regarding the position, function, and authority between the two state institutions by involving experts or neutral national figures. Revising from the aspect of the legislation is included.
\end{abstract}

Keywords: Building, Relationship, Judicial commission, Supreme Court

\begin{abstract}
ABSTRAK
Fenomena hubungan antar KY dan MA mengalami pasang surut dan masih mengalami banyak salah tafsir dan belum ada paradigma yang sama sehingga jika dibiarkan bisa berdampak luas terhadap penegakan hukum dan keadilan dalam sistem peradilan di Indonesia. Banyak aspek yang perlu dibangun minimal membangun paradigma, mengevaluasi bebrbagai tugas dan wewenang masing-masing agar menghasilkan hubungan yang harmonis dan sinergitas yang kuat. Berdasarkan problematika hubungan kedua lembaga negara tersebut, penulis tertarik untuk mengkaji dan membahas tentang "Membangun hubungan Komisi Yudisial dengan
\end{abstract}


Mahkamah Agung yang Ideal". Untuk mengkaji dan membahas lebih mendasar dan mendalam tentang hal tersebut penulis merumuskan permasalahan sebagai berikut "Bagaimana upaya membangun hubungan yang ideal antara Komisi Yudisial dengan Mahkamah Agung ? Metode yang digunakan sesuai dengan jenis penelitian yaitu yuridis normatif, dengan menggunakan bahan-bahan hukum primer dan sekunder, sedangkan analisis yang digunakan analisis yuridis kualitatif. Kesimpulanya adalah paradigma hubungan yang harus dibangun antara KY dan MA adalah paradigma kesetaraan, sistemik, profesionalitas dan proporsionalitas. Upaya yang dilakukan adalah memperkuat komunikasi, kordinasi dan mengkaji serta mengevaluasi berbagai hambatan dan kelemahan mengenai kedudukan, fungsi dan wewenang antara kedua lembaga negara tersebut dengan melibatkan para ahli atau tokoh tokoh bangsa yang netral. Termasuk membenahi dari aspek perarturan peundangundangannnya.

Kata Kunci: Membangun, Hubungan, Komisi yudisial dan Mahkamah Agung

\section{PENDAHULUAN}

Semangat reformasi untuk melakukan penataan terhadap sistem ketatanegaraan,dan kehidupan berbangsa dan bernegara telah diletakkan fondasinya di dalam UndangUndang Dasar Negara Republik Indonesia Tahun 1945. Penataan sistem ketatanegaraan dimaksud dalam rangka mewujudkan perubahan dan perbaikan disemua aspek kehidupan sesuai dengan paradigma dan visi berbangsa dan bernegara.

Paradigma dan visi Indonesia berbangsa dan bernegara adalah mewujudkan kehidupan berkebangsaan yang bebas, merdeka, bersatu, adil dan makmur. Untuk mewujudkan paradigma dan visi tersebut membutuhkan suatu upaya yang serius, menyeluruh, komprehensif dan berkelanjutan. Aspek penataan dalam bidang hukum khsususnya di bidang sistem peradilan,penegakan hukum dan keadilan merupakan salah satu yang urgen untuk perhatikan.

Urgensi terhadap penataan di bidang hukum dimaksud dilandasi oleh prinsip negara hukum sebagaimana yang terkandung di dalam Pasal 1 ayat 3 UUD NRI Tahun 1945. Prinsip negara hukum tersebut tidak akan memiliki makna aksilogis apapun bila dalam manajemen penyusunan produk hukum, pelaksanaan dan penegakan hukum masih diwarnai pemikiran dan sikap perbuatan yang tidak konsisten. Ketidakkonsisten tersebut merupakan akar dan awal dari carut marut dan runtuhnya kewibawaan hukum di negara kita, yang berimplikasi pada perbuatan curang, koruptif kolutif dan pelanggaran hukum lainnya.

Perbuatan yang demikian tersebut akan sangat berbahaya untuk kelangsungan kehidupan berbangsa dan bernegara, apalagi dilakukan oleh para aparat penegak hukum yaitu polisi, jaksa penuntut umum, hakim dan advokat. Fenomena yang terjadi dalam dunia peradilan seperti mafia peradilan, persekongkolan antar penegak hukum atau antar aparat atau antara penegak hukum dengan pihak yang berperkara serta yang berkaitan dengan pelanggaran etik dan perilaku hakim akan menambah panjang sejarah kelam dunia peradian dan penegakan hukum di Indonesia.

Sejarah kelam tersebut sudah seharusnya dihentikan atau paling tidak diminimalisir secara bertahap melalui pembenahan, pembinaan dan pengawasan terhadap para aparat penegak hukum termasuk melakukan pengawasan perilaku dan etiknya. Oleh karena itu sangat tepat bila dalam rangka pembenahan, pembinaan dan pengawasan tersebut Pemerintah membentuk beberapa komisi penegak hukum yaitu komisi kepolisan, komisi kejaksaan, dewan kehormatan advokat, dan komisi yudisial. 
Dari beberapa komisi dan dewan kehormatan etik tersebut, ternyata Komisi Yudisial memiliki keistimewaan dan kekhususan. Keistimewaannya dimaksud terletak pada penempatan dan pengaturannya yang langsung di dalam UUD NRI Tahun 1945 sebagaimana diatur pada Bab IX tentang kekuasaan kehakiman, yaitu dalam Pasal 24A ayat (3) dan Pasal 24B. Pasal 24 A ayat (3) menyebutkan bahwa calon hakim agung diusulkan Komisi Yudisial kepada Dewan Perwakilan Rakyat untuk mendapatkan persetujuan dan selanjutnya ditetapkan sebagai hakim agung oleh Presiden. Selanjutnya Pasal 24 B ayat (1) menyebutkan Komisi Yudisial bersifat mandiri yang berwenang mengusulkan pengangkatan hakim agung dan mempunyai wewenang lain dalam rangka menjaga dan menegakkan kehormatan, keluhuran, martabat, serta perilaku hakim.

Hal itu berbeda dengan komisi-komisi penegak hukum yang lain yang derajat pengaturannya hanya diatur dalam Undang-Undang. Perbedaan penempatan dan pengaturan tersebut secara tidak langsung dapat dimaknai dan dipahami bahwa keberadaan Komisi Yudisial tersebut merupakan lembaga negara yang memiliki kedudukan yang sangat kuat dan penting dalam rangka menjaga dan mengawal perilaku hakim dan pembenahan sistem peradilan di Indonesia.

Keistimewaan lainnya, Komisi Yudisial memiliki kewenangan mengusulkan calon hakim agung dan wewenang lain dalam rangka menjaga dan menegakkan kehormatan keluhuran martabat serta perilaku hakim. Selanjutnya dari aspek kekhususannya, tentu apabila ada keinginan untuk membubarkan dan merubah yang berkaiatan dengan Komisi Yudisial maka harus melalui prosedur yang sangat khusus dan ketat sesuai dengan mekanisme perubahan yang diatur oleh UUD NRI tahun 1945.

Dalam kedudukan dan kewenangan yang kuat serta stimewa tersebut dalam praktik tidak jarang mengalami berbagai hambatan dan dinamika terutama dalam hubungannya dengan insttusi kekuasaan kehakiman khususnya Mahkamah Agung. Sebagai contoh misalnya Mahkamah Agung pernah berbeda pandangan dengan Komisi Yudisial dalam menilai kasus mantan hakim PN Jakarta Selatan yang bernama Sarpin Rizaldi, sehingga Mahkamah Agung menolak seluruh rekomendasi yang diberikan oleh Komisi Yudisial.

Menurut Mahkamah Agung saudara Sarpin tidak melakukan kesalahan yang bersifat teknis yuridis maupun etik dan pedoman perilaku hakim sebagaimana yang diputuskan para anggota lembaga pengawas hakim pada pleno mereka. Dari perbendaan pandangan antar dua lembaga negara tersebut muncul polemik dan menyebabkan hubungan kedua lembaga negara tersebut sempat tegang dan renggang bahkan terlihat kurang harmonis. Ketegangan dan kerenggangan hubungan tersebut dapat juga disebabkan karena terjadinya perbedaan penafsiran tentang substansi ruang lingkup tupoksi masing-masing.

Fenomena hubungan antar KY dan MA juga ternyata memberi persepsi pada masyarakat bahwa KY adalah lembaga macan ompong. Padahal cara kerja KY berbeda, yakni bersifat rahasia. Tugas KY yang paling utama adalah menjaga, bukan menegakkan. Sehingga sistem pelaksanaan tugas pengawasan di KY tidak diekspos secara masif seperti kinerja lembaga lainnya. KY adalah lembaga etik, sehingga dalam menjalankan tugasnya haruslah tetap menerapkan asas presumption of innoncent. Bahkan jika dikenakan sanksi pun KY masih menjaga hakim tersebut, karena profesi hakim adalah profesi yang mulia. Berbeda dengan profesi lainnya ."Jika dikatakan KY macan ompong, saya tidak bisa memberikan komentar. Karena yang terpenting kami 
di KY bekerja dalam senyap. Sebab sebagai lembaga etik, yang disentuh adalah hati, bukan raganya," pungkas Juru Bicara KY ini ${ }^{1}$.

Selain itu bisa jadi disebabkan karena masih dominannya pengaruh paradigma lama di tubuh petinggi Mahkamah Agung yang secara subjektif merasa memiliki kewajiban dan tanggungjawab untuk membela korp hakim di lingkungan peradilan dibawah yurisdiksinya, agar marwah dan nama baik organisasi peradilan dan pejabat hakim secara organisatoris selalu terjaga dan tidak tercoreng di mata masyarakat. Hal itu terindikasi dari beberapa fakta dimana tidak sedikit rekomendasi dari Komisi Yudisial yang tidak ditindaklanjuti oleh Mahkamah Agung.

Peristiwa dan kejadian yang dapat menggerogoti dan mendistorsi hubungan antara Komisi Yudisial dengan Mahkamah Agung di masa yang lalu tersebut tidak bisa dibiarkan dan dianggap sepele, sebab hal tersebut dapat berdampak pada tidak produkifnya kinerja kedua lembaga negara yang pada gilirannya dapat merugikan kepentingan masyarakat luas khususnya masyarakat pencari keadilan. Oleh oleh karena itu merupakan keniscayaan untuk disikapi dan dicari solusi alternatifnya, agar kualitas penegakan hukum dan keadilan dimasa yang akan datang şemakin lebih baik dan dirasakan manfaatnya oleh masyarakat, bangsa dan negara.

Berdasarkan problematika hubungan kedua lembaga negara tersebut, penulis tertarik untuk mengkaji dan membahas tentang "Membangun hubungan Komisi Yudisial dengan Mahkamah Agung yang Ideal". Untuk mengkaji dan membahas lebih mendasar dan mendalam tentang hal tersebut penulis merumuskan permasalahan sebagai berikut "Bagaimana upaya membangun hubungan yang ideal antara Komisi Yudisial dengan Mahkamah Agung?

\section{METODE PENELITIAN}

Jenis penelitian ini adalah yuridis normatif. Berdasarkan jenis penelitian dimaksud maka pendekatan digunakan adalah pendekatan hukum dan peraturan perundangundangan. Sesuai dengan jenis penelitian yang ditetapkan tersebut maka bahan hukum yang penulis gunakan bahan hukum primer dan sekunder. Bahan hukum primer berupa UndangUndang Dasar Negara Republik Indonesia Tahun 1945, Undang-Undang Republik Indonesia Nomor 18 tahun 2011 tentang Perubahan atas Undang-Undang Nomor 22 tahun 2004 tentang Komisi Yudisial, Undang-Undang Republik Indonesia Nomor 3 tahun 2009 tentang perubahan kedua atas Undang-Undang Nomor 14 tahun 1985 tentang Mahkamah Agung dan Undang-Undang 48 tahun 2009 tentang Kekuasaan Kehakiman, sedangkan bahan hukum skunder berupa buku-buku dan artikel para akademisi yang relevan dengan permasalahan yang akan dibahas. Adapun metode analisis yang digunakan adalah analisis yuridis kualitatif.

\section{PEMBAHASAN}

\section{A. Identifikasi Penyebab Potensial Timbulnya Problematik Hubungan Antara Komisi Yudisial Dengan Mahkamah Agung}

Mencermati perkembangan dinamika pasang surut hubungan antara Komisi Yudisial dengan Mahkamah Agung, maka perlu dicari beberapa aspek potensial penyebab timbulnya problematik hubungan antara kedua lembaga negara tersebut yang sering mencuat ke permukaan, sehingga hubungan kedua lembaga negara tersebut terkesan

${ }^{1}$ https://komisiyudisial.go.id/frontend/news detail/396/hubungan-ky-dan-ma-adalah-dinamikalembaga, pukul 9.44 Wib.tanggal 6 Desember 2021. 
kurang harmonis dan mengarahkan pada konflik. Untuk itu penulis mencoba mengidentifikasi beberapa aspek potensial problematik hubungan yaitu;

\section{Aspek Ego-kelembagaan;}

Munculnya problematik hubungan antara Komisi Yudisial dengan Mahkamah Agung dapat disebabkan oleh aspek ego-kelembagaan, hal ini terlihat adanya pola pikir dan sikap para elit Mahkamah Agung yang merasa memiliki kelebihan dan lebih bewenang membina dan mengawasi para hakim dari pada Komisi Yudisial. Pola pikir dan sikap yang demikian dilatarbelakangi oleh faktor keberadaan Mahkamah Agung dianggap lebih dahulu dan lebih memahami tentang problem intern Mahkamah Agung, apalagi jika berkaitan dengan persoalan pembinaan dan pengawasan para hakim, terkesan Mahkamah Agung selalu melindungi korpnya. Faktor tersebut salah satu potensi yang ikut mendominasi munculnya ego-kelembangaan.

\section{Aspek kesalahtafsiran ruang lingkup kewenangan}

Aspek kesalahtafsiran mengenai ruang lingkup dan yurisdiksi substansi kewenangan masing-masing lembaga masih terlihat menjadi salah satu aspek potensial. Hal ini terbukti dengan sering tidak ditindaklanjuti oleh Mahkamah Agung atas rekomendasi Komisi Yudisial terhadap para hakim yang diangggap bermasalah. Sebagai contoh kasus misalnya, kasus mantan Hakim Sarpin Rizaldi sangat jelas terjadinya tafsiran yang berbeda antara Komisi Yudisial dan Mahkamah Agung.

Selain perbedaan tafsir tentang ruang lingkup kewenangan juga disebabkan oleh kelemahan dari norma yang terdapat dalam Pasal 24B ayat (1) yang menyebutkan bahwa wewenang Komisi Yudisial tersebut selain pengusulan pengangkatan hakim agung juga ada kata "wewenang lain" dalam rangka menjaga dan menegakkan kehormatan, keluhuran martabat serta perilaku hakim.

Makna "wewenang lainnya" dalam Pasal tersebut menimbulkan pemahaman tafsiran yang berbeda, tergantung pada kepentingan yang menafsirkannya, dan bisa dipersempit dan bisa juga diperluas. Bisa juga tergantung pada elit pembentuk Undang-Undang yang merumuskannya. Hal tersebut sejalan dengan apa yang jelaskan oleh Sukma Violetta ${ }^{2}$,Wakil Ketua Komisi Yudisial dalam menanggapi persoalan lemahnya rekomendasi Komisi Yudisial atas Mahkamah Agung, Sukma mengatakan perbedaan penafsiran menyebabkan rekomendasi Komisi Yudisial seringkali tidak ditindaklanjuti oleh Mahkamah Agung. Mahkamah Agung menganggap kewenangan Komisi Yudisial tidak termasuk aspek teknis yudisial dalam menangani perkara," Hal itu termasuk dalam mempertimbangkan alat bukti, serta mempertimbangkan saksi diterima atau tidak. Kewenangan Komisi Yudisial dilihat Mahkamah Agung hanya terbatas di area perilaku atau kode etik. Pernyataan tersebut ada relevansinya dengan pendapat $\mathrm{Ahmad}^{3}$;

"Dalam perkembangannya, meskipun keberadaan Komisi Yudisial diatur secara Eskplisit dalam undang-Undang Dasar 1945, namun tidak serta merta menjadi sebuah lembaga negara yang memiliki kewenangan super, khususnya setelah adanya

2 https://www.komisiyudisial.go.id/frontend/news_detail/60/aidul-sukma-pimpin-ky, dikutip tanggal 14 Mei 2020 pukul 21.38. tanggal 6 Desember 2021.

3 Ahmad Dalam Eka N.A.M Sihombing dan Ali Marwan Hsb (editor), Paradigma Hukum Ketatanegaraan Indonesia Dalam rangka Hari Ualng Tahun ke-90 Prof.dr.M. solly Lubis, SH. Enam Media, 2020, hlm. 280-281. 
putusan Mahkamah konstitusi Nomor 005/PUU-IV/2006, yang diucapkan pada 23 Agustus 2006, Dengan putusan MK itu, keberadaan KY pun menjadi tidak terlalu relevan dalam sistem ketatanegaraan jika wewenangnya hanya mngusulkan pengangkatan hakim agung kepada DPR........., padahal melalui lembaga KY ini, diharapkan dapat diwujudkan lembaga peradilan yang sesuai dengan harapan rakyat sekaligus dapat diwujudkan penegakan hukum dan pencapaian keadilan melalui putusan hakim yang terjaga kehormatan dan keluhuran martabat dan perilakunya."

Pendapat Ahmad di atas, paling tidak secara akademis mendeskripsikan bahwa begitu besarnya harapan terhadap peran dan fungsi Komisi Yudisial dalam rangka membangun dan menegakkan hukum serta keadilan melalui suatu putusan hakim.Putusan hakim yang adil dan memenuhi aspek kepastian hukum serta kemanfaatan tentu akan hadir bila pembenahan lembaga peradilan secara menyeluruh dan sistemik. Berbicara tentang sistem secara umum, Lili Rasjidi ${ }^{4}$, mengingatkan bahwa kemampuan hukum untuk menyelenggarakan fungsinya sangat ditentukan oleh kemampuan komponen-komponen sistemnya, baik secara otonom, maupun dalam kerangka sistem sebagai suatu keseluruhan. Lemahnya salah satu komponen sistem, akan membawa pengaruh besar terhadap gerak sistem itu.

\section{Aspek kurangnya kesadaran dalam satu sistem}

Kesadaran terhadap tugas, fungsi dan wewenang antara Komisi Yudisial dan Mahkamah Agung sebagai satu sistem masih kurang. Akibatnya ada kesan bahwa keberadaan kedua lembaga negara bekerja dalam ranahnya masing-masing, bahkan ada kecendrungan seperti kompetitor, padahal sesungguhnya bila dicermati substansi kewenangan antara kedua lembaga negara tersebut berada dalam sistem yaitu dalam satu kesatuan kekuasaan kehakiman yang saling melengkapi dan memperkuat untuk meningkatkan kinerja para hakim guna menegakkan hukum dan keadilan.

\section{B. Paradigma Dan Upaya Membangun Hubungan Antara Komisi Yudisial Dengan Mahkamah Agung Yang Ideal \\ 1. Paradigma}

Istilah paradigma secara historis diperkenalkan pertama kali oleh Thomas Kuhn sekitar tahun 1962, dan selanjutnya di definiklan oleh Robert Freidrichs tahun 1970. Secara etimologis, istilah paradigma berasal dari bahasa Yunani yaitu dari kata "para" yang artinya di sebelah atau pun di samping, dan kata "diegma" yang artinya teladan, ideal, model, atau pun arketif. Sedangkan secara terminologis, istilah paradigma diartikan sebagai sebuah pandangan atau pun cara pandang yang digunakan untuk menilai dunia dan alam sekitarnya, yang merupakan gambaran atau pun perspektif umum berupa cara - cara untuk menjabarkan berbagai macam permasalahan dunia nyata yang sangat kompleks. Menurut Robert Freidrichs, paragigma merupakan kumpulan tata nilai yang membentuk pola pikir seseorang sebagai titik tolak pandangannya sehingga terbentuk citra subjektif seseorang terhadap ralita sehingga berujung pada ketentuan bagaimana cara untuk menangani realita tersebut. Thomas Kuhn, mengartikan paradigma adalah landasan berpikir atau pun konsep dasar yang

${ }^{4}$ Lili Rasjidi, Dalam Sri Rahayu oktoberina dan Niken Savitri (penyunting), Butir-Butir Pemikiran dalam Hukum, Memperingati 70 Tahun Prof.Dr.B.Arief Sidharta, Refika Abandung, 2008, ditama, hlm 129-130 
digunakan / dianut sebagai model atau pun pola yang dimaksud para ilmuan dalam usahanya, dengan mengandalkan studi - studi keilmuan yang dilakukannya ${ }^{5}$.

Dalam membangun konsep hubungan antara Komisi Yudisial dan Mahkamah Agung tentu yang sangat penting terlebih dahulu harus ditata dan dibangun adalah paradigma sebagai pedoman dan pemandu bersama dalam menjalakan fungsi dan wewenangnya masing. Sebab tanpa adanya paradigma dimaksud tentu akan berpotensi terjalinnya hubungan yang semu dan memungkinkan terjadi kesalahpahaman, kesalahtafsiran dalam melihat sesuatu permasalahan. Dalam melihat dan menilai sesuatu masalah dan kasus tersebut ,tergantung pada kacamata dan perpsektif masing-masing lembaga.

Penulis berpendapat bahwa paradigma yang dibangun dalam hubungan Komiisi Yudisial dengan Mahkamah Agung adalah paradigma kesetaraan -sistemikprofesional dan proporsional. Kesetaraan artinya suatu cara berpikir dan bersikap antara KY dan MA dibangun atas dasar hubungan yang sederajat Sistemik artinya kedua lembaga negara tersebut merupakan satu kesatuan secara sistem dalam rangka membangun peradilan yang bersih, berwibawa dan berkeadilan. Profesional artinya kedua lembaga negara tersebut dalam menjalankan fungsi dan wewenangnya masingmasing saling menghormati dan tidak saling intervensi. Proporsional artinya kedua lembaga negara dimaksud dalam menjalankan fungsi dan wewenangnnya tetap membangun sinergitas sesuai dengan hak dan kewajibannnya masing-masing.

Untuk itu secara filsafati ketataneggaraan sudah seharusnya para pejabat masing-masing kedua lembaga negara tersebut harus memahami dan menyadari terlebih dahulu keberadaan, tugas dan wewenang masing-masing dan saling memahami eksistensi tugas dan wewenang lembaga negara lainnya. Mahkamah Agung adalah lahir dan dibentuk sebagai atribut negara hukum dalam rangka menegakkan hukum dan keadilan. Filasat ketatanegaraannya adalah hadir mewakili negara dalam mewujudkan nilai kebenaran dan keadilan dalam negara. Begitu pula Komisi Yudisial merupakan conditio sine quanon hadir dan lahir sebagai atribut negara hukum dan negara demokrasi untuk mengawal dan patner Mahkamah Agung dalam menegak hukum dan keadilan yang substantif. Paradigma tersebut di atas minimal harus dibangun dan disepakati oleh para pimpinan dan anggota kedua lembaga negara baik secara konseptual maupun dalam pelaksanaannya.

Setelah paradigma tersebut sudah terbangun dan terinternalisasi ke dalam masing-masing lembaga negara melalui pejabatnya, maka dijabarkan dalam kreteria ideal hubungan antara kedua lembaga melalui kesepahaman yang berbasis tugas dan wewenang masing masing. Artinya atas dasar kreteria yuridis konstitusional di dalam Pasal 24, Pasal 24A dan Pasal 24B UUD NRI Tahun 1945 selanjutnya dijabarkan dalam Undang-Undang, maka paradigma ideal hubungan antara kedua lembaga negara dimaksud sebagai berikut ;

1. Mahkamah Agung dan Komisi Yudisial harus membangun paradigma kesetaraan-sistemik, profesionalitas dan proporsionalitas dalam rangka menjalakan fungsi dan wewenangnya masing-masing, sehingga saling menghormati dan tidak saling intervensi

2. Mahkamah Agung dan Badan Peradilan di bawahnya menjalankan; a. kekuasaan kehakiman yang merdeka untuk b. menyelenggarakan sistem peradilan yang

\footnotetext{
${ }^{5}$ https://pengertiandefinisi.com/pengertian-paradigma/pukul 10.48. tanggal 6 Desember 2021.
} 
objektif dan transparan c. hanya semata-mata menegakkan "hukum dan keadilan"

3. Komisi Yudisial bersifat "mandiri" yang wewenangnya mengusulkan pengangkatan hakim agung

4. Komisi Yudisial memiliki wewenang lain dalam rangka menjaga dan menegakkan kehormatan, keluhuran martabat, serta perilaku hakim.

5. Komisi Yudisial lembaga negara yang bersifat mandiri sebagai patner Mahkamah Agung yang sederajat dan setara dalam rangka mencari, menyeleksi dan mendapatkan Hakim Agung yang berkualitas, berintegritas dan memiliki kemampuan untuk menegakkan hukum dan keadilan

6. Komisi Yudisial lembaga negara yang merupakan patner Mahkamah Agung dalam menjaga dan menegakkan kehormatan, keluhuran martabat dan periaku hakim. Disini jelas Komisi Yudisial memiliki kontribusi yang sangat besar dalam menjaga martabat, kehormatan hakim agar hakim berperilaku yang bak, tidak tercela dan benar secara etik guna bersinergi dengan Mahkamah Agung dalam proses menjalankan kekuasaan kehakiman yang merdeka .

7. Titik temu hubungan antara Komisi Yudisial dengan Mahkamah Agung terletak pada sinergitas kewenangan menjaga etik dan perilaku para hakim, sehingga titik temunya berada pada aspek pembinaan dan pengawasan, Mahkamah Agung menjaga hakim dari aspek pembinaan dan pengawasan secara hirarkis internal, sedangkan Komisi Yudisial menjaga harkat martabat etik hakim sebagai bentuk pengawasan ekternal.

Titik hubungan kedua lembaga negara tersebut secara yuridis telah diumuskan di dalam Pasal 13 Undang-Undang Nomor 18 Tahun 2011 tentang Perubahan Atas Undang-Undang Nomor 22 Tahun 2004 tentang Komisi Yudisial, Komisi Yudisial mempunyai wewenang sebagai berikut:

1. Mengusulkan pengangkatan hakim agung dan hakim ad hoc di Mahkamah Agung kepada DPR untuk mendapatkan persetujuan;

2. Menjaga dan menegakkan kehormatan, keluhuran martabat, serta perilaku hakim;

3. Menetapkan Kode Etik dan/atau Pedoman Perilaku Hakim (KEPPH) bersamasama dengan Mahkamah Agung;

4. Menjaga dan menegakkan pelaksanaan Kode Etik dan/atau Pedoman Perilaku Hakim (KEPPH).

Pasal 20 Undang-Undang Nomor 18 Tahun 2011 mengatur bahwa:

1. Dalam rangka menjaga dan menegakkan kehormatan, keluhuran martabat, serta perilaku hakim, Komisi Yudisial mempunyai tugas:

- Melakukan pemantauan dan pengawasan terhadap perilaku hakim;

- Menerima laporan dari masyarakat berkaitan dengan pelanggaran

Kode Etik dan Pedoman Perilaku Hakim;

- Melakukan verifikasi, klarifikasi, dan investigasi terhadap laporan dugaan pelanggaran Kode Etik dan Pedoman Perilaku Hakim secara tertutup; 
- Memutus benar tidaknya laporan dugaan pelanggaran Kode Etik dan Pedoman Perilaku Hakim,

- Mengambil langkah hukum dan/atau langkah lain terhadap orang perseorangan, kelompok orang, atau badan hukum yang merendahkan kehormatan dan keluhuran martabat hakim.

2. Selain tugas sebagaimana dimaksud pada ayat (1), Komisi Yudisial juga mempunyai tugas mengupayakan peningkatan kapasitas dan kesejahteraan hakim;

3. Dalam rangka menjaga dan menegakkan kehormatan, keluhuran martabat, serta perilaku hakim, sebagaimana dimaksud pada ayat (1) huruf a, Komisi Yudisial dapat meminta bantuan kepada aparat penegak hukum untuk melakukan penyadapan dan merekam pembicaraan dalam hal adanya dugaan pelanggaran Kode Etik dan/atau Pedoman Perilaku Hakim oleh Hakim.

4. Aparat penegak hukum wajib menindaklanjuti permintaan Komisi Yudisial sebagaimana dimaksud pada ayat (3).

Turunan dari paradigma dan visi bernegara tersebut juga di atur di dalam Undang-Undang Nomor 3 tahun 2009 tentang perubahan kedua atas Undang-Undang Nomor 14 tahun 1985 di dalam Pasal 8 dan Pasal 11A dan Pasal 32 A yang mengatur wewenang masing-masing dalam bidang pengawasan termasuk menyusun dan membentuk peraturan kode etik dan pedoman perilaku hakim secara bersama-sama. Demikian pula dalam Pasal 11A mengatur tentang pemberhentian Hakim Agung yang berkaiatan dengan wewenang Komisi Yudisial. Pengaturan hubungan kewenangan kedua lembaga negara ini telah diatur pula di dalam Undang-undang Nomor 48 tahun 2009 tentang kekuasaan kehakiman.

Paradigma konstitusional dan yuridis formal tersebut sesungguhnya merupakan pedoman dan pegangan bagi kedua lembaga negara dalam menjalankan wewenang dan tugasnya masing. Wewenang dan tugas yang diatur dalam suatu paradigma tersebut akan kurang efektif bila para elit kedua lembaga tersebut tidak konsisten dan saling menjaga dan menghormati satu sama lainnya. Memang sudah menjadi kodrat suatu produk hukum bahwa bagaimanapun baik dan lengkapnya suatu peraturan perundang-undangan tidak akan memiliki kepastian dan aksiologis dalam implementasinya bila para pelaksana dan penegak hukum tidak konsisten mematuhinya. Demikian juga dengan paradigma hubungan dimaksud, juga tidak akan ada manfatnya bila para stacholder di dalamnya tidak bersepakat untuk mempedomaninya.

\section{Upaya}

Berpedoman pada aspek potensial penyebab timbul problematik hubungan antara Komisi Yudisial dengan Mahkamah Agung tersebut di atas, maka penulis mencermati bahwa sesungguhnya ditataran formil atau permukaan telah ada upaya dari elit/pejabat kedua lembaga negara dimaksud untuk mencoba memecahkan problem-problem yang muncul. Misalnya adanya berbagai pertemuan, diskusi dan pembahasan bersama sesuai dengan peraturan perundang-undangan yang berlaku, baik itu berdasarkan Undang-Undang Nomor 48 tahun 2009 tentang Kekuasaan Kehakiman, UndangUndang Nomor 18 tahun 2011 tentang Komisi Yudisial maupun Undang-Undang Nomor 3 tahun 2009 tentang Mahkamah Agung sebagai Undang-Undang Perubahan. Namun problematik tersebut sesungguhnya belum juga dapat meredam permasahan hubungan antar kedua lembaga negara tersebut. 
Hal tersebut disebabkan satu sisi Komisi Yudisial dengan kedudukan dan tanggungjawabnya yang diberikan oleh konstitsui menganggap tugas dan wewenang yang diberikan oleh Undang-Undang yang berlaku masih belum lengkap dan tuntas, hal itu terbukti dengan ada pemikiran dari pimpinan Komisi Yudisial untuk merubah undang-undang yang ada, misalnya agar komisi ini diberikan wewenang untuk menjatuhkan sanksi terhadap hakim-hakim yang terbuki melanggar peraturan etik dan peraturan perilaku hakim. Namun disisi lain tentu Mahkamah Agung merasa wewenang semacam itu tidak perlu dan itu terlalu meluas dan melebar.

Perbedaan pandangan semacam itu akan selalu menghangat dan mencuat sampai kapanpun. Oleh karena penulis menawarkan pemikiran bahwa perlu dirumuskan secara objektif oleh badan atau lembaga yang independen minimal kalangan Perguruan Tinggi atau tokoh bangsa dan ahli hukum yang teruji kenetralannya untuk menggodok dan mengkaji substansi wewenang dan tugas Komisi Yudisial dan juga mengkaji substansi wewenang dan tugas Mahkamah Agung.

Selain itu, sambil menunggu persoalan mengenai wewenang dan tugas masingmasing tuntas daalam bentuk sebuah Undang-Undang, tentu dalam upaya membangun hubungan antara Komisi Yudisial dan Mahkamah Agung tersebut diperlukan suatu kesadaran dan pemahaman tentang adanya sinergitas hubungan kedua lembaga negara itu dalam satu sistem bernegara yaitu sama-sama menjalankan paradigma dan visi berbangsa dan bernegara sebagai mana yang telah penulis uraikan dalam bagian pendahuluan. Pemahaman dan kesadaran para elit kedua lembaga negara tersebut terhadap paradigma dan visi bernegara tentu akan melepaskan dan menguburkan egokelembagaan, kesalahtafsiran ruang lingkup kewenangan, dan akan tumbuh dan terbangunnya kesadaran akan pentingnya kedua lembaga negara ini bekerja dalam satu sistem yang saling membutuhkan dan saling melengkapi dan saling memperkuat untuk perbaikan dan pembenahan sistem peradilan sebagai esensi dalam menjalankan kekuasaan kehakiman yang merdeka dan berdaulat dalam menjaga tegaknya hukum dan keadilan.

Kedua elit lembaga negara tersebut harus sadar dan memahami dengan sungguh bahwa kehadiran kedua lembaga negara itu, bukan untuk kepentingan institusi masingmasing, tetapi untuk kepentingan tegaknya hukum dan keadilan di republik ini, untuk kepentingan bangsa dan negara, sehingga apapun pemikiran yang muncul kalau untuk perbaikan dan pembenahan maka saat itulah kenegarawan para elit khsususnya Mahakamah Agung dibutuhkan. Juga sebaliknya para elit Komisi Yudisial harus juga memahami bahwa Mahkamah Agung itu adalah patner kerja dalam rangka mewujudkan sistem peradilan yang merdeka, bersih, transparan dalam rangka tegaknya hukum dan keadilan, oleh karena itu Komisi Yudisial tetap bekerja secara profesional dan proporsional.

Upaya lain, tentu suatu keniscayaan untuk membangun kordinasi, sinkronisasi, komunikasi dan sinergitas antar elit kedua lembaga negara tersebut secara profesional, dan proporsional dalam satu paradigma dan visi berbangsa dan bernegara di dalam satu sistem ketatanegaraan sebagaimana termaktub dalam UUD NRI Tahun 1945.

\section{KESIMPULAN}

Berdasarkan uraian di atas, penulis berkesimpulan; bahwa problemtaik hubungan antara Komisi Yudisial dan Mahkamah Agung disebabkan oleh beberapa aspek, yaitu a. Aspek masih kuatnya ego-kelembagaan, b. Aspek kesalahtafsiran ruang lingkup kewenangan, c. Aspek kurangnya kesadaran dalam satu sistem. Atas dasar problematik 
tersebut maka upaya untuk membangun hubungan antara Komisi Yudisial dengan Mahkamah Agung idealnya harus didasarkan pada paradigma kesetaraan, sistemik, profesionalitas dan proporsionalitas . Untuk mendukung paradigma tersebut maka asas kemitraan, setara atau sederajat ,kesepahaman dan kesadaran para elit kedua lembaga negara tersebut terhadap paradigma dan visi bernegara. Yang tidak kalah urgennya pula dalam membangun hubungan yang ideal antara kedua lembaga negara dimaksud tentu untuk melepaskan dan menguburkan ego-kelembagaan, kesalahtafsiran ruang lingkup kewenangan, dan menumbuhkan dan membangun kesadaran akan pentingnya kedua lembaga negara ini bekerja dalam satu sistem yang saling membutuhkan dan saling melengkapi, saling menghargai dan saling memperkuat untuk perbaikan dan pembenahan sistem peradilan sebagai esensi dalam menjalankan kekuasaan kehakiman yang merdeka dan berdaulat dalam menjaga tegaknya hukum dan keadilan. Disamping terus membangun kordinasi, sinkronisasi, komunikasi dan sinergitas antar elit kedua lembaga negara tersebut secara profesional, dan proporsional dalam satu paradigma dan visi berbangsa dan bernegara di dalam satu sistem ketatanegaraan sebagaimana termaktub dalam UUD NRI Tahun 1945.

\section{SARAN}

Sebagai sumbang saran penulis untuk menjembati perbedaan dan problematik hubungan kedua lembaga negara tersebut, hendaknya perlu dirumuskan secara objektif oleh badan atau lembaga yang independen minimal kalangan Perguruan Tinggi atau tokoh bangsa dan ahli hukum yang teruji kenetralannya untuk memformulasikan bersama-sama dengan wakil-wakil dari MA dan KY tentang paradigma hubungan yang ideal sebagaimana yang dijelaskan di atas, sambil mengevaluasi dan mengkaji ulang tentang substansi kedudukan, fungsi dan wewenang masing-masing kedua lembaga negara yaitu Komisi Yudisial dan Mahkamah Agung dari aspek hukum konstitusi dan peraturan perundang-undangan yang berlaku.

\section{UCAPAN TERIMA KASIH}

Dengan selesainya tulisan ini penulis ucapkan terima kasih kepada Bapak Rektor Universitas Bhayangkara Jaya, Dekan Fakultas Hukum Ubhara Jaya dan Pimpinan PS MIH Ubhara Jaya, serta Ibu Dr. Lely Arrianie, M.Si yang ikut mendukung secara moral, finasial dan sekaligus menjadi editor dari tulisan ini. Juga kepada Dr. Sugeng, SH.MH sekretaris Magister Ilmu Hukum yang mendorong penulis untuk menulis tulisan ini sehingga terbitnya tulisan ini. Semoga ada manfaatnya., Aamin Yra. 


\section{DAFTAR PUSTAKA}

\section{Buku-Buku}

Ahmad, Dalam Eka N.A.M Sihombing dan Ali Marwan Hsb (editor), Paradigma Hukum ,Ketatanegaraan Indonesia Dalam rangka Hari Ualng Tahun ke-90 Prof.dr.M. solly Lubis, SH. Enam Media, 2020.

Lili Rasjidi, Dalam Sri Rahayu oktoberina dan Niken Savitri (penyunting), Butir-Butir Pemikiran dalam Hukum, Memperingati 70 Tahun Prof.Dr.B.Arief Sidharta, Refika Aditama, Bandung, 2008,

\section{Peraturan Perundang-Undangan}

Undang-Undang Dasar Negara republik Indonesia tahun 1945

Undang-Undang Nomor 48 tahun 2009 tentang Kekuasaan Kehakiman

Undang-Undang Nomor 18 tahun 2011 tentang Komisi Yudisial

Undang-Undang nomor 3 tahun 2009 tentang Mahkamah Agung

\section{Internet}

https://www.komisiyudisial.go.id/frontend/news_detail/60/aidul-sukma-pimpin- ky, dikutip tanggal 14 Mei 2020 pukul 21.38.

https://komisiyudisial.go.id/frontend/news_detail/396/hubungan-ky-dan-ma-adalahdinamika-lembaga, pukul 9.44 Wib.tanggal 6 Desember 2021.

https://pengertiandefinisi.com/pengertian-paradigma/pukul 10.48. tanggal 6 Desember 2021. 